\title{
Comparison of praziquantel pharmacokinetics and tissue distribution in fresh and brackish water cultured grass carp (ctenopharyngodon idellus) after oral administration of single bolus
}

Xinyan Xie, Yini Zhao, Xianle Yang and Kun Hu

\begin{abstract}
Background: Praziquantel (PZQ) is an effective pesticide against monogeneans. Its pharmacokinetics in fish may be affected by water environment and temperature. The present study was designed to compare the pharmacokinetics, tissue distribution, and elimination of PZQ in freshwater-acclimated grass carp and brackish water cultured grass carp. Plasma and tissue PZQ concentrations were determined after a single $10 \mathrm{mg} / \mathrm{kg}$ oral PZQ dose.

Results: The datas of plasma and tissues drug concentration was calculated by the software SPSS 13.0. According to the One-Way ANOVA, the results showed that the salinity had a significant effect on the drug concentration of plasma $(p<0.01)$, muscle $(p<0.01)$, liver $(p<0.01)$ and kidney $(p<0.01)$ in the all sampling time points between the brackish water grass carps and the freshwater grass carps, wherein, PZQ plasma and tissue concentrations in the brackish water group were constantly lower than that in the freshwater group. The peak PZQ levels of plasma, muscle, liver, and kidneys in the brackish water group were $0.76 \mu \mathrm{g} / \mathrm{ml}, 0.51 \mu \mathrm{g} / \mathrm{g}, 2.7 \mu \mathrm{g} / \mathrm{g}$, and $2.99 \mu \mathrm{g} / \mathrm{g}$, respectively; and that in the freshwater group were $0.91 \mu \mathrm{g} / \mathrm{ml}, 0.62 \mu \mathrm{g} / \mathrm{g}, 3.87 \mu \mathrm{g} / \mathrm{g}$, and $3.39 \mu \mathrm{g} / \mathrm{g}$, respectively. The elimination half-lives ( $\mathrm{t}_{1 / 2 \beta}$ ) in plasma and all tissues of the freshwater group were significantly longer than that in the brackish water group. The elimination half-lives $\left(t_{1 / 2 \beta}\right)$ of plasma, muscle, liver and kidneys in brackish water grass carps were $56.46,36.17,15.31$, and $132.64 \mathrm{~h}$, respectively; and that in the freshwater grass carps were $71.15,44.88,23.86$, and $150.23 \mathrm{~h}$, respectively.

Conclusion: These findings indicate that water environment affects the tissue distribution and elimination of PZQ in grass carps, the elimination in brackish water grass carps is more rapid than that in fresh water grass carps and tissue concentrations of brackish water grass carps are lower than that in freshwater grass carps after orally administrating the same dosage at the same water temperature. We speculate that the main excretion pathway of the drug is through renal elimination, and the decreased kidney function in brackish water grass carps is likely responsible for the considerable difference in pharmacokinetics between the two groups of grass carps.
\end{abstract}

Keywords: Praziquantel, Pharmacokinetics, Grass carp, Salinity, Tissue distribution, Elimination

\footnotetext{
* Correspondence: khu@shou.edu.cn

College of Aquaculture and Life Science, Shanghai Ocean University, No. 999,

Huchenghuan Road, Shanghai 200090, P.R. China
} 


\section{Background}

Praziquantel (PZQ) is widely used as a chemotherapeutic agent for treating helminths in captive fish. It is effective against monogeneans that infect the gills, skin, and branchial cavities [1-13], larval and encysted digeneans infecting the eyes [14] and skin [15], as well as intestinal cestodes [16] of teleosts and elasmobranchs.

Grass carp (Ctenopharyngodon idellus) is an economically important species of farmed fish. In China, grass carp has a widespread breeding distribution scope, covering different salinity areas in the eastern and northwestern regions, and freshwater areas of the central and southern regions. For example, the water salinity of Lian Yungang in Jiangsu province is $3.6 \%$ and that of Tachen Island in Zhejiang province is $5.8 \%$ [17]. Several studies have indicated that environmental water salinity can influence the accumulation and elimination of chemicals in fish [18-22]. The difference in pharmacokinetics influences the effectiveness of PZQ in aquaculture, especially for treating monogenean infection in brackish water cultured grass carps.

Chemical/drug pharmacokinetics in aquatic animals can be affected by various environmental factors, such as water temperature, $\mathrm{PH}$, and salinity [23]. However, the effect of salinity is often overlooked, especially in freshwater fish. Moreover, in order to improve grass carp muscle quality, the fish are often raised in brackish water or placed into brackish water for a period of time before listing [24]. Considering that grass carp are cultured in both freshwater and brackish water, it is necessary to investigate possible tissue distribution and praziquantel elimination differences in grass carp under different water environments. We believe that this study would help better formulate effective PZQ regimens in treating monogenean infections of fish.

\section{Methods}

\section{Chemicals and reagents}

Praziquantel (2-cyclohexyl-carbonyl-4-oxo-1,2,3,6,7,11bhexahydro-4Hpyrazino[2,1-a] isoquinoline) (99.9\% purity) is used as an analytical standard and was purchased from Sigma-Aldrich (St. Louis, MO, USA); PZQ (purity 98\%) used in the pharmacokinetic study was purchased from Feng Hua Pharmaceutical Co., Ltd., Hebei. HPLCgrade acetonitrile was purchased from Merck (KGaA, Germany); and all the other chemicals were of analytical grade.

\section{Animals}

All the experiment fish precedures were reviewed and approved by the Institutional Animal Care and Use Committee at Shanghai Ocean University at Shanghai Ocean University. According to the Shanghai ocean university animal health guidelines for animal care and experimentation. About 120 six month age Grass carps (Ctenopharyngodon idellus, weighing $80 \pm 5.6 \mathrm{~g}$ ) were obtained from Nantong Fisheries Farm (Yancheng, China) and were randomly divided into two groups: freshwater group and brackish water group and number of fish in each group was 60 . The two groups of fish were brought in the laboratory and placed in two ponds $\left(1 \mathrm{~m}^{3}\right)$. The brackish water group was gradually acclimated to brackish water with $3.5 \%$ salinity for five days; circulating water (the salinity for the freshwater and brackish water groups were 0 and $3.5 \%$, respectively) and oxygen were continuously supplied using an inflation pump. Before the experiment, the two groups were acclimated in rearing tanks for 10 days at $22 \pm 1^{\circ} \mathrm{C}$. During acclimation, they were fed twice daily with a drug-free commercial diet to apparent satiation, then starved for $24 \mathrm{~h}$ before drug administration.

\section{Drug administration}

To prepare the PZQ dosing solution, PZQ was dissolved in $5 \mathrm{~mL}$ of ethanol and mixed with water to achieve a final concentration of $2 \mathrm{~g} / \mathrm{L}$. The fish were given $5 \mu \mathrm{L} / \mathrm{g}$ of the PZQ solution via gavage using a stomach tube -with the final PZQ dosage being $10 \mathrm{mg} / \mathrm{kg}$. After oral drug administration, each fish was placed in an observation tank for five minutes for possible drug regurgitation; regurgitated fish were excluded from the analysis.

\section{Sample collection}

Blood sampleswere collected from the tail sinus of five fish at various time points (before dosing; and 0.25, 0.5, $1,3,6,12,24,48$, and $96 \mathrm{~h}$ after dosing); then, five fish in each sampling time point were killed by breaking their spine. Muscle, liver, and kidney samples were taken, immediately frozen, and stored at $-20^{\circ} \mathrm{C}$ until analysis.

\section{Sample preparation}

The analytical procedure for PZQ analysis was modified according to the report of Jing Yao [25]. In brief, the plasma $(1 \mathrm{~mL})$ or ground tissue samples $(1 \mathrm{~g})$ were separately placed into $50-\mathrm{ml}$ centrifuge tubes, and mixed with $3 \mathrm{ml}$ of ethylacetate using a Vortex vibration meter (Thermo Fisher Scientific, USA) for three minutes. After 10 minutes of centrifugation at $4,500 \mathrm{rpm}$, the supernatant was removed and transferred to a $15 \mathrm{ml}$ centrifuge tube. The extraction step was repeated once. The combined ethyl acetate extracts were evaporated at $45^{\circ} \mathrm{C}$ to dryness using the rotary evaporation apparatus (Eppendorf, Germany). Residues were reconstituted with $1 \mathrm{ml}$ of HPLC mobile phase, in which $2 \mathrm{ml}$ of hexane was added. The mixture was vortexed for three minutes and centrifuged at $8,000 \mathrm{rpm}$ for two minutes. The supernatant was 
removed and transferred to a 2 -ml centrifuge tube; then $20 \mu \mathrm{L}$ was injected onto the HPLC system, as described below.

\section{Chromatographic conditions}

We used an Agilent (HP1100) HPLC system with a fluorescence detector. The separation was performed on a Zorbax XDB-C18 column $(4.6 \times 150 \mathrm{~mm}$ internal diameter, $5-\mu \mathrm{m}$ particle size; Agilent Technologies, USA) using an isocratic mixture of acetonitrile: water $(50: 50, \mathrm{v} / \mathrm{v})$ as the mobile phase at a constant flow rate of $1 \mathrm{ml} / \mathrm{min}$. Injection volume was $20 \mu \mathrm{L}$, optical maser wavelength was $265 \mathrm{~nm}$, emission wavelength was $280 \mathrm{~nm}$, and column temperature was $25^{\circ} \mathrm{C}$.

\section{Pharmacokinetic analysis}

Pharmacokinetic analysis was performed using the DAS 3.0 program; and pharmacokinetic parameters were analyzed based on the classical compartmental analysis for plasma and tissue concentration-time data. The following pharmacokinetic parameters were estimated: $\mathrm{C}_{\max }$ (peak concentration), $t_{1 / 2 \alpha}$ (half-life of the absorption rate constant), $t_{1 / 2 \beta}$ (half-life of the elimination rate constant), $\mathrm{AUC}_{(0-\mathrm{t})}$ (area under the concentration-time curve from time zero to $\mathrm{t}$ ), and $\mathrm{CL} / \mathrm{F}$ (total body clearance).

\section{Statistical analysis}

Statistical analysis between the two groups was completed using the SPSS 13.0 program.

\section{Results}

\section{Analytical method validation}

The analytical procedure for PZQ analysis was modified according to the report of Jing Yao [25]. A linear calibration curve over the $0.05-20 \mu \mathrm{g} / \mathrm{ml}$ PZQ range was established, yielding a correlation coefficient exceeding 0.9994. The drug concentration of the samples above the upper calibration limit was diluted with blank plasma and supernatants of the tissue samples. The results showed that all inter-day and intra-day coefficients of variation were below $3.34 \%$; while tissue sample accuracy ranged from $74 \%$ to $85 \%$, and mean recovery was above $76 \%$. Based on a signal-to-noise ratio $>3$, the lower limits of detection (LOD) and quantitation (LOQ) for this assay were $0.05 \mu \mathrm{g} / \mathrm{mL}$.

\section{Pharmacokinetic analysis}

The PZQ concentration-time curves are shown in Figure 1. The pharmacokinetic parameters are shown in Table 1. The plasma, muscle and liver of freshwater group grass carp and the plasma, muscle and kidney of brackish water group PZQ concentration-time profiles were best

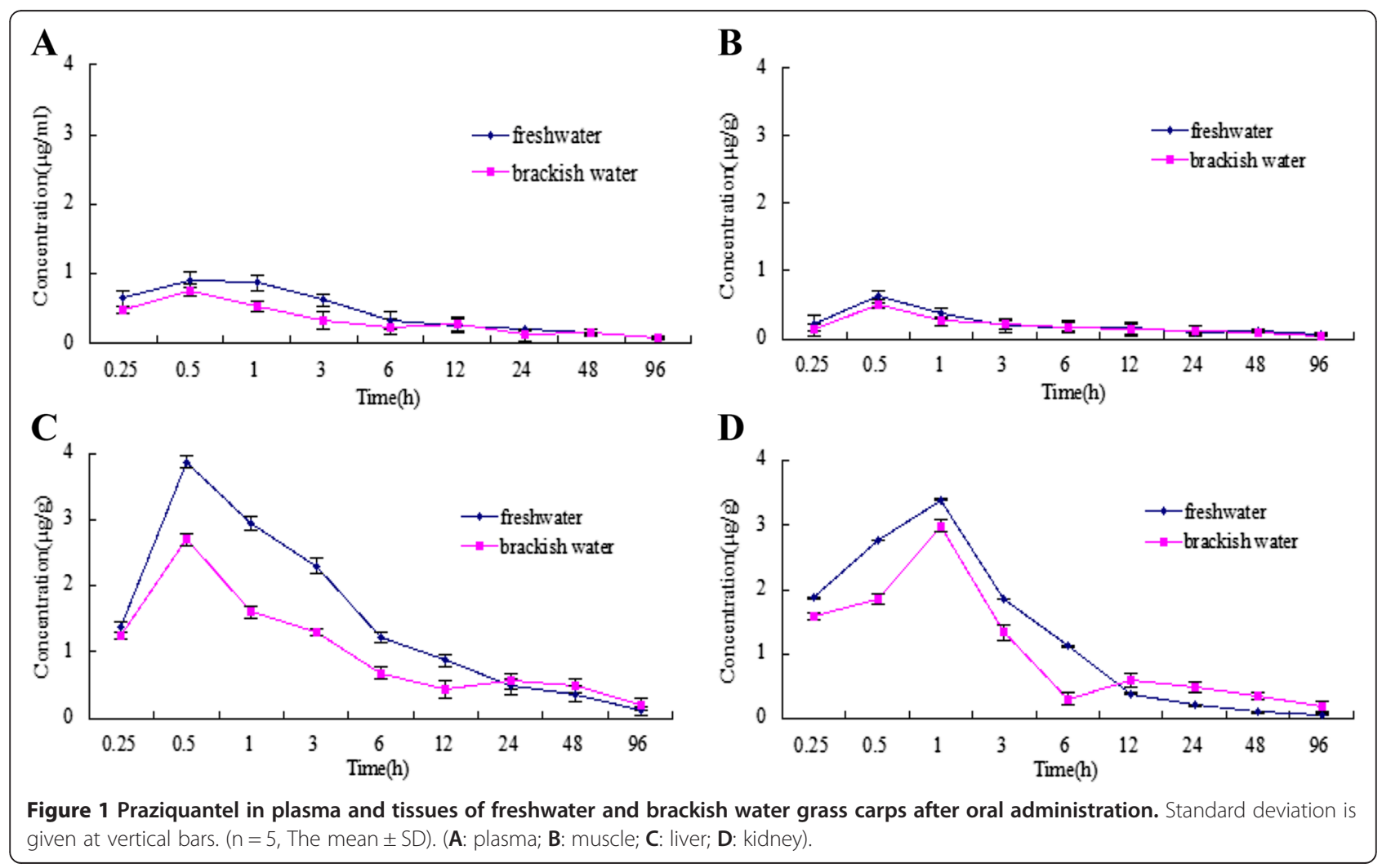


Table 1 Pharmacokinetic parameters of Praziquantel in grass carp $(n=5)$

\begin{tabular}{|c|c|c|c|c|c|c|c|c|c|}
\hline \multirow[b]{2}{*}{ Parameter } & \multirow[b]{2}{*}{ Unit } & \multicolumn{2}{|c|}{ Plasma } & \multicolumn{2}{|c|}{ Muscle } & \multicolumn{2}{|l|}{ Liver } & \multicolumn{2}{|l|}{ Kidney } \\
\hline & & $\begin{array}{l}\text { Fresh } \\
\text { water }\end{array}$ & $\begin{array}{l}\text { Brackish } \\
\text { water }\end{array}$ & $\begin{array}{l}\text { Fresh } \\
\text { water }\end{array}$ & $\begin{array}{l}\text { Brackish } \\
\text { water }\end{array}$ & $\begin{array}{l}\text { Fresh } \\
\text { water }\end{array}$ & $\begin{array}{l}\text { Brackish } \\
\text { water }\end{array}$ & $\begin{array}{l}\text { Fresh } \\
\text { water }\end{array}$ & $\begin{array}{l}\text { Brackish } \\
\text { water }\end{array}$ \\
\hline $\mathrm{C}_{\max }$ & $\mathrm{ug} /(\mathrm{g}$ or $\mathrm{ml})$ & 0.91 & 0.76 & 0.62 & 0.51 & 3.87 & 2.70 & 3.39 & 2.99 \\
\hline$T_{\max }$ & h & 0.5 & 0.5 & 0.5 & 1 & 0.5 & 0.5 & 1 & 1 \\
\hline$t_{1 / 2 a}$ & h & 3.25 & 1.85 & 0.31 & 1.12 & 0.35 & 2.69 & 0.76 & 2.87 \\
\hline$t_{1 / 2 \beta}$ & h & 71.15 & 56.46 & 44.88 & 36.17 & 23.86 & 15.31 & 150.23 & 132.64 \\
\hline$t_{1 / 2 K a}$ & h & 0.16 & 0.028 & 0.058 & 0.57 & 0.15 & 0.031 & 0.307 & 0.64 \\
\hline V1/F & L/kg & 23.57 & 30.15 & 21.53 & 22.22 & 28.38 & 97.33 & 34.30 & 87.17 \\
\hline $\mathrm{CL} / \mathrm{F}$ & L/h/kg & 0.755 & 1.042 & 1.961 & 0.974 & 0.481 & 0.308 & 1.878 & 0.350 \\
\hline$A \cup C_{(0-t)}$ & $\mu g / L \cdot h$ & 17.951 & 14.614 & 8.096 & 6.865 & 34.984 & 44.047 & 10.411 & 38.663 \\
\hline$A \cup C_{(0-\infty)}$ & $\mu \mathrm{g} / \mathrm{L} \cdot \mathrm{h}$ & 26.464 & 19.189 & 10.196 & 20.515 & 41.547 & 64.823 & 10.645 & 57.132 \\
\hline K10 & $1 / h$ & 0.064 & 0.035 & 0.091 & 0.044 & 0.17 & 0.048 & 0.34 & 0.16 \\
\hline K12 & $1 / h$ & 0.235 & 0.212 & 1.574 & 0.474 & 1.469 & 0.113 & 2.034 & 0.754 \\
\hline K21 & $1 / \mathrm{h}$ & 0.104 & 0.14 & 0.548 & 0.103 & 0.355 & 0.036 & 0.245 & 0.042 \\
\hline $\mathrm{Ka}$ & $1 / \mathrm{h}$ & 4.201 & 25.183 & 11.951 & 1.203 & 4.537 & 22.106 & 2.26 & 1.082 \\
\hline
\end{tabular}

$\mathrm{C}_{\max }$, the peak concentration in plasma; $T_{\max }$, the time point of the drug's maximum plasma concentration; $t_{1 / 2 a}$, distribution half-life of the drug; $t_{1 / 2 \beta}$, elimination half-life of the drug; $t_{1 / 2}$ Ka, absorption half-life of the drug; $V 1 / F$, extensive apparent volume of the central compartment; $C L / F$, total body clearance of the drug; $\mathrm{AUC}_{(0-\mathrm{t})}$, area under the concentration-time curve from $0 \mathrm{~h}$ to $\mathrm{t}$; $\mathrm{AUC}_{(0-\infty)}$, area under the concentration-time curve from $0 \mathrm{~h}$ to $\infty$; $\mathrm{K} 12$, $\mathrm{K} 21$, first-order rate constants for drug distribution between the central and peripheral compartments; K10, elimination rate constant from the central compartment; Ka, absorption rate constant.

described by a two-compartmental open pharmacokinetic model with first-order absorption. The kidney of freshwater group and liver of brackish water group PZQ concentration-time profiles were best described by a threecompartmental open pharmacokinetic model. The datas of plasma and tissues drug concentration was calculated by the software SPSS 13.0. According to the One-Way ANOVA, the results showed that the salinity had a significant effect on the drug concentration of plasma $(p<0.01)$, musle $(p<0.01)$, liver $(p<0.01)$ and kidney $(p<0.01)$ in the all sampling time points between the brackish water grass carps and the freshwater grass carps.

\section{PZQ distribution and elimination}

Tissue concentrations are shown in Figure 1. The absorption of PZQ in freshwater grass carps was essentially the same as the brackish water carps. There were no significant differences in $\mathrm{T}_{\max }$ of plasma, liver, and kidneys between the two groups.

The mean peak levels in plasma, muscle, liver and kidneys of the brackish water grass carps were 0.76, 0.51, 2.7 , and $2.99 \mu \mathrm{g} / \mathrm{g}$, respectively; which were lower than that in the freshwater grass carps $(0.91,0.62,3.87$, and $3.39 \mu \mathrm{g} / \mathrm{g}$, respectively). In most sampling time points, the plasma and tissue PZQ levels in brackish water grass carps were lower than that in the freshwater grass carps.

The plasma and tissue PZQ elimination half-lives $\left(t_{1 / 2 \beta}\right)$ in brackish water grass carps were shorter than that in the freshwater grass carps (Table 1). The PZQ elimination half-lives $\left(\mathrm{t}_{1 / 2 \beta}\right)$ in plasma, muscle, liver and kidneys of the brackish water grass carps were 56.46, $36.17,15.31$, and $132.64 \mathrm{~h}$, respectively; and the figures for freshwater grass carps were $71.15,44.88,23.86$, and $150.23 \mathrm{~h}$, respectively. These findings indicated that PZQ elimination in brackish water grass carps was more rapid than that in freshwater grass carps.

\section{Discussion}

Monogeneans can rapidly multiply in intensive farming facilities [26], necessitating early diagnosis, as well as rapid and effective treatment, to prevent benign infections from becoming pathogenic. PZQ is a useful chemotherapeutic against helminths of captive fish. There is a need for examining factors that affect its pharmacokinetics in order to minimize the potential development of anthelmintic resistance caused by extended exposure of parasites to subcurative doses [27].

Salinity conditions play an important role in pharmacokinetics and fish tissue residues. For example, oxolinic acid presents in lower concentrations for a longer period of time in seawater teleosts than freshwater teleosts [17]. Ishida [19] reported that oxolinic acid is excreted more slowly in freshwater trout than in seawater trout. Abedini et al. [20] suggested that freshwater trout may be used as a salmonid model to study oxytetracycline pharmacokinetics in seawater salmon; however, drug elimination and clearance rates in freshwater trout are remarkably lower than that in seawater salmon. Feng et al. [21] 
demonstrated that tissue drug concentrations of seawater tilapia are lower than that in freshwater tilapia; and the elimination of florfenicol in seawater tilapia is more rapid than that in freshwater tilapia. Even though grass carps could live in both fresh and brackish waters, possible PZQ pharmacokinetic differences between freshwater-acclimated grass carps and brackish water grass carps have never been reported.

In the present study, the datas of plasma and tissues drug concentration was showed that the salinity had a significant effect on the drug concentration of plasma $(p<0.01)$, muscle $(p<0.01)$, liver $(p<0.01)$ and kidney $(p<0.01)$ in the all sampling time points between the brackish water grass carps and the freshwater grass carps. The plasma PZQ concentration-time curve patterns were similar in the two groups, which could be best described by a two-compartmental open pharmacokinetic model with first-order absorption.

The $\mathrm{CL} / \mathrm{F}$ is the total body clearance of the drug and the $t_{1 / 2 \beta}$ is the elimination half-life of the drug. The two pharmacokinetics parameters can describe how quickly the drug is eliminated from the fish. The CL/F of the freshwater group and brackish water grass carp plasma were 0.755 and $1.042 \mathrm{~L} / \mathrm{h} / \mathrm{kg}$ respectively. The elimination half-lives $\left(t_{1 / 2 \beta}\right)$ of plasma in freshwater water grass carps and brackish grass carp were 71.15 and $56.46 \mathrm{~h}$, respectively. Compare to the freshwater grass carps, the brackish water grass carps have more rapidly drug clearance and shorter elimination half-lives when the grass carp cultured in the low salinity water. The water salinity change will influence the regulation of osmotic pressure in the grass carps. Even though seawater salinity is greater than brackish water, the results indicated that osmoregulation still existed in brackish water fish, and that their drug excretion pathway may be altered. The results were consistent with previous similar studies $[18,20,21]$.

K12 and K21 were the first-order rate constants for drug distribution between the central and peripheral compartments. The datas display that the K12 and K21 of the brackish water group grass carp were lower than that of freshwater group in most tissues such as liver and kidney. This phenomenon indicated that the salinity water could decrease the drug distribution rate between the central and peripheral compartments.

In the most sampling time points, the liver drug concentrations of the brackish water group are lower than that of freshwater group which water has no salinity; indicating that water salinity can affect drug metabolism in the liver, and that the drug may be eliminated through other drug excretion pathways, such as branchial excretion. Sohlberg et al. [28] reported that gill excretion occurs in seawater fish; Atlantic salmon excrete approximately $60 \%$ of administered flumequine through the gills in seawater. Feng et al. [21] reported that branchial excretion competence in seawater fish may be attributed to active drinking for osmoregulatory purposes of seawater tilapia; possibly resulting to the rapid excretion of the drug and its metabolites or their ionized complexes via the branchial chloride cells.

Kidneys are the main organs that excrete drugs and its metabolites. When the water has no salinity, the PZQ concentration in kidney was gently rising in the previous time points. Strangely, the PZQ concentration of brackish water grass carp kidneys slowly increased between 0.25 and $0.5 \mathrm{~h}$ after dosing, which peaked between 0.5 and $1 \mathrm{~h}$; indicating that water salinity can also affect brackish water fish kidneys due to osmoregulation result in kidney weakening function. For grass carps in brackish water, the drug and its metabolites are likely to stay in the body and be reabsorbed by entero-hepatic cycling to some extent, retarding drug elimination due to the decrease in urine output through osmoregulation. When the renal drug concentration of brackish water grass carps slowly increased to its peak concentration between 0.25 and $0.5 \mathrm{~h}$ after dosing, the drug concentrations of the other tissues decreased. This phenomenon illustrated that the drug in the surrounding tissues entered the kidneys at that time, increasing the kidney drug concentration to its peak concentration; which again rapidly declined after micturition.

\section{Conclusion}

In summary, our results indicate that salinity level greatly impacts the accumulation and tissue distribution of PZQ in grass carps, and that its elimination in brackish water grass carps is more rapid than that in fresh water grass carps. Further, tissue concentrations of brackish water grass carps are lower than that in freshwater grass carps, after orally administrating the same dosage at the same water temperature. We speculate that the main excretion pathway of the drug is through renal elimination, and the decreased kidney function in brackish water grass carps is likely responsible for the considerable difference in pharmacokinetics between the two groups of grass carps.

\section{Competing interests}

The authors declare that they have no competing interests.

\section{Authors' contributions}

$X Y X$ completed the main part of experiment and drafted the manuscript. YNZ carried out the immunoassays. KH participated in the design of the study and performed the statistical analysis. XLY conceived of the study, and participated in its design and coordination. All authors read and approved the final manuscript.

\section{Acknowledgements}

This study was supported by the 863 Program (Grant No. 2011AA10A216), the Special Fund for Agro-scientific Research in the Public Interest (Grant No.201203085) and Shanghai Ocean University Knowledge Service Platform. 
Received: 24 October 2014 Accepted: 19 March 2015

Published online: 01 April 2015

\section{References}

1. Schmahl G, Mehlhorn H. Treatment of fish parasites. 1. Praziquantel effective against monogenea (Dactylogyrus vastator, Dactylogyrus extensus, Diplozoon paradoxum). Zoo Para. 1985;71:727-37.

2. Schmahl G, Taraschewski H. Treatment of fish parasites. 2. Effects of praziquantel, niclosamide, levamisoleHCl, and metrifonate on monogenea (Gyrodactylus aculeati, Diplozoon paradoxum). Parasitol Res. 1987;73:341-51.

3. Thoney DA. The effects of trichlorfon, praziquantel and copper sulphate on various stages of the monogenean Benedeniella posterocolpa, a skin parasite of the cownose ray, Rhinoptera bonasus (Mitchill). J Fish Dis. 1990;13:385-9.

4. Kim KH, Park SI, Jee BY. Efficacy of oral administration of praziquantel and mebendazole against Microcotyle sebastis (Monogenea) infestations of cultured rockfish (Sebastes schlegeli). Fish Pathol. 1998;33:467-71.

5. Hirazawa N, Ohtaka T, Hata K. Challenge trials on the anthelmintic effect of drugs and natural agents against the monogenean Heterobothrium okamotoiin the tiger puffer Takifugu rubripes. Aquaculture. 2000;188:1-13.

6. Chisholm LA, Whittington ID. Efficacy of praziquantel bath treatments for monogenenean infections of the Rhinobatos typus. J Aquat Anim Health. 2002;14:230-4.

7. Stephens FJ, Cleary JJ, Jenkins G, Jones JB, Raidal SR, Thomas JB. Treatments to control Haliotremaabaddon in the West Australian dhufish. Glaucosoma hebraicum Aquaculture. 2003;215:1-10.

8. Janse M, Borgsteede FHM. Praziquantel treatment of captive white-spotted eagle rays (Aetobatus narinari) infested with monogenean trematodes. Bull Eur Assoc Fish Pathol. 2003;23:152-6.

9. Sharp N, Diggles BK, Poortenaar CW, Willis TJ. Efficacy of Aqui-S, formalin and praziquantel against the monogeneans, Benedenia seriolaeand Zeuxapta seriolae, infecting yellowtail kingfish Seriola lalandi lalandiin New Zealand. Aquaculture. 2004;236:67-83.

10. Hirazawa N, Mitsuboshi T, Hirata T, Shirasu K. Susceptibility of spotted halibut Verasper variegatus (Pleuronectidae) to infection by the monogenean Neobenedenia girellae (Capsalidae) and oral therapy trials using praziquantel. Aquaculture. 2004;234:83-95.

11. Hayward CJ, Bott NJ, Itoh N, Iwashita M, Okihiro M, Nowak BF. Three species of parasites emerging on the gills of mulloway. Argyrosomus japonicas Aquaculture. 2007;1-4:27-40.

12. Buchmann K, Kania PW, Neumann L, de' Besi G. Pseudodactylogyrosis in Anguilla anguilla (Actinopterygii: Anguilliformes: Anguillidae): change of control strategies due to occurrence of anthelmintic resistance. Acta Ichthyologica Et Piscatoria. 2011;2:105-8.

13. Hirazawa N, Akiyama K, Umeda N. Differences in sensitivity to the anthelmintic praziquantel by the skin-parasitic monogeneans Benedenia seriolae and Neobenedenia girellae. Aquaculture. 2013;404-405:59-64.

14. Bylund G, Sumari O. Laboratory tests with Droncit against diplostomiasis in rainbow trout, Salmo gairdneri Richardson. J Fish Dis. 1981;4:259-64.

15. Mitchell AJ. Importance of treatment duration for praziquantel used against larval digenetic trematodes in sunshine bass. J Aquat Anim Health. 1995;7:327-30.

16. Sanmartin Duran ML, Caamano-Garcia F, Fernandez Casal J, Leiro J, Ubeira FM. Anthelminthic activity of praziquantel, niclosamide, netobimin and mebendazole against Bothriocephalus scorpiinaturally infecting turbot (Scophthalmus maximus). Aquaculture. 1989;76:199-201.

17. Zuo J, Yu Y, Chen Z. The analysis of sea level variation factor along China coast. Advance Earth Sci. 1994;5:48-53.

18. Ishida N. Comparison of tissue-level of oxolinic acid in fresh and sea-water fishes after the oral-administration. Nippon Suisan Gakkaishi. 1990;2:281-6.

19. Tachikawa M, Sawamura R, Okada S, Hamada A. Differences between freshwater and seawater killifish (Oryzias latipes) in the accumulation and elimination of pentachlorophenol. Arch Environ Contam Toxicol. 1991;21:51-146.

20. Ishida N. Tissue levels of oxolincic acid after oral or intravascular administration to freshwater and seawater rainbow trout. Aquaculture. 1992;102:9-15.

21. Abedini S, Namdari R, Law FCP. Comparative pharmacokinetics and bioavailability of oxytetracycline in rainbow trout and chinook salmon. Aquaculture. 1998;1:23-32.
22. Jing-Bin F, Xiao-Ping J, Liu-Dong L. Tissue distribution and elimination of florfenicol in tilapia (Oreochromis niloticus\&x\&O. caureus) after a single oral administration in freshwater and seawater at $28^{\circ} \mathrm{C}$. Aquaculture. 2008;1-4:29-35.

23. Zhang $H$, Zhao M, Zhuang Z. The research status of domestic fishery drug metabolism dynamics. Progress Veterinary Med. 2010;31:138-43.

24. Li X, Li X, Leng X, Liu X, Wang X, Li J. The effect of salinity on growth of grass carp and muscle quality. Journal Fisheries China. 2007;31:343-8.

25. Jing Yao. The Toxicities and pharmacokineties Residues of Praziquantel on Goldfish (Catassiusauratus) by oral and bath treatment. Master thesis. Sichuan Agricultural University, College of Veterinary Medicine; 2007

26. Ernst I, Whittington I, Corneillie S, Talbot C. Monogenean parasites in sea-cage aquaculture. Austasia Aquaculture. 2002;1:46-8.

27. Tubbs LA, Tingle MD. Bioavailability and pharmacokinetics of a praziquantel bolus in kingfish Seriola lalandi. Dis Aquat Organ. 2006;2-3:233-8.

28. Sohlberg S, Martinsen B, Horsberg TE, Søli NE. Excretion of flumequine in free-swimming Atlantic salmonSalmo salar, determined by cannulation of the dorsal aorta, gall bladder and urethra. J Vet Pharmacol Ther. 1999;22:72-5.

\section{Submit your next manuscript to BioMed Central and take full advantage of:}

- Convenient online submission

- Thorough peer review

- No space constraints or color figure charges

- Immediate publication on acceptance

- Inclusion in PubMed, CAS, Scopus and Google Scholar

- Research which is freely available for redistribution 